DOI https://doi.org/10.15589/znp2021.1(484).6 УДК 662.65

\title{
ANALYSIS OF DIRECT BIOMASS COMBUSTION PROCESS IN INDUSTRIAL ROTARY FURNACES
}

\section{АНАЛІЗ ПОЦЕСУ ПРЯМОГО СПАЛЮВАННЯ БІОМАСИ В ПРОМИСЛОВИХ ОБЕРТОВИХ ПЕЧАХ}

\author{
Anatoliy A. Lysenko ${ }^{1}$ \\ lysenko.a.ig@gmail.com \\ ORCID: 0000-0002-3108-0993 \\ Mykyta V. Vorobiov ${ }^{2}$ \\ vorobiov.nikv@gmail.com \\ ORCID: 0000-0001-9621-7658
}

\author{
А. А. Лисенко ${ }^{1}$ \\ науковий співробітник
}

М. В. Воробйов ${ }^{2}$

канд. техн. наук, старший викладач

${ }^{1}$ Gas Institute of the National Academy of Sciences of Ukraine, Kyiv

${ }^{2}$ National Technical University of Ukraine “Igor Sikorsky Kyiv Polytechnic Institute”, Kyiv

${ }^{1}$ Інститут газу Начіональної академії наук Украйни, м. Київ

${ }^{2}$ Національний технічний університет України

«Київський політехнічний інститут імені Ігоря Сікорського», м. Київ

\begin{abstract}
The purpose of the paper is researches the processes of direct combustion of biomass (sunflower husk, wood particles) in industrial rotary kilns to replace natural gas in order to save energy. The staging of research is due to the high cost of fossil fuels, in particular natural gas, and leads to the need to constantly search for new cheap alternative energy sources. Methodology - the approach of the theoretical analysis of processes of burning of biomass taking into account technological features of work of rotary kilns was used. Results - the features of direct combustion of biomass (sunflower husk, wood particles) in industrial rotary kilns are investigated in the work. The analysis of the potential of biofuels for the replacement of natural gas in Ukraine showed that the use of the theoretical potential of biogas production from biofuels is possible at the level of 0.68 million tons AD. The stages of combustion of biofuel particles are typical of the solid fuel combustion and the combustion process includes such steps as the processes of moisture evaporation, release (evaporation) of volatile combustible substances and combustion of carbon and CO. When carrying out the process of biomass combustion, a high degree of energy use must be ensured due to the complete combustion of biofuel particles while complying with the relevant environmental requirements. Scientific novelty - it has been established that in rotary kilns, new alternative fuels for direct combustion can be such specific fuels as car tire recycling products, meat and bone meal, wood waste, sewage sludge, paper and plastics. Practical significance the conducting analysis makes it possible to state that the use of biomass is able to provide the necessary technological requirements for the operation of rotary kilns. It is possible to completely replace natural gas with alternative fuels in industrial plants, which is confirmed by the appropriate use of alternative fuels in advanced industrial enterprises in Europe and the world.
\end{abstract}

Key words: biomass; biofuel; industrial rotating furnaces; direct combustion; sunflower husk; woodchips.

Анотація. Мета роботи - дослідження процесів прямого спалювання біомаси (лушпиння соняшника, частинок деревини) в промислових обертових печах для заміщення природного газу з метою економії енергоресурсів. Постановка роботи викликана високою вартістю викопного палива, зокрема природного газу, та призводить до необхідності постійного пошуку нових дешевих альтернативних джерел енергії. Методика - використовувався підхід теоретичного аналізу процесів спалювання біомаси з врахуванням технологічних особливостей роботи обертових печей. Результати - у роботі досліджені особливості прямого спалювання біомаси (лушпиння соняшника, частинок деревини) у промислових обертових печах. Виконаний аналіз потенціалу біопалива для заміщення природного газу на території України показав, що використання теоретичного потенціалу виробництва біогазу з біопалива можливо на рівні 0,68 млн. т н.е. Стадії горіння частинки біопалива $є$ типовими при вигоранні твердого палива та при протіканні процесу горіння, послідовно протікають процеси випаровування вологи, виходу (випаровування) летючих горючих речовин та горіння вуглецю і СО. При здійсненні процесу 


\section{ТЕПЛОЕНЕРГЕТИКА № 1 2021}

горіння біомаси має забезпечуватися високий ступінь використання енергії через повне вигорання частинок біопалива одночасно з додержанням відповідних екологічних вимог. Наукова новизна: встановлено, що в обертових печах новими альтернативними видами палива для прямого спалювання може бути таке специфічне паливо, як продукти переробки автомобільних шин, м'ясо-кісткове борошно, деревні відходи, осад стічних вод, папір і пластмаси. Практична значимість - проведений аналіз дає можливість стверджувати, що використання біомаси здатне забезпечити необхідні технологічні вимоги роботи обертових печей. Можливою $є$ повна заміна природного газу на альтернативне паливо в промислових установках, що підтверджується відповідним використанням альтернативних палив на передових промислових підприємствах Європи та світу.

Ключові слова: біомаса; біопаливо; промислові обертові печі; пряме спалювання; лушпиння соняшника; частинки деревини.

\section{ПОСТАНОВКА ЗАДАЧІ}

Висока вартість енергії і ресурсів, зокрема природного газу, призводить до необхідності постійного пошуку нових альтернативних джерел енергії. Крім того, величина шкідливих викидів традиційної енергетики призводить до більшої готовності і до більш широкого використання альтернативних видів палива у всьому світі.

У сучасній промисловості посилюється екологічна і фінансова мотивація заміни традиційного викопного палива альтернативним паливом, а саме паливом, отриманим з біомаси або відходів [1-3].

У всьому світі використання альтернативних видів палива у виробництві складає більше 12,5\% теплової енергії, з якої близько 77\% отримують з відходів, а $23 \%$ - 3 біомаси [3; 4]. Біомаса $є$ найекологічнішим джерелом первинної енергії. Ї̈̈ використання постійно динамічно зростає, причому не тільки через іiі вигідну ціну, а й через її вплив на навколишнє середовище [1; 3]. Біомаса є найдоступнішим на сьогодні паливом i, на відміну від нафти, природного газу або вугілля, іiі досить всюди, в т.ч. і в Україні, і вона є відновлюваним джерелом енергії. До основних видів біомаси, придатних для енергетичних цілей слід віднести деревну і рослинну біомаси.
У світових умовах і в умовах України метою прямого спалювання біомаси $\epsilon$ вироблення тепла, отримання газу, електрики чи в сукупності $[1 ; 2 ; 4]$. Для отримання дешевої енергії необхідно використовувати найдешевше і доступне за ціною паливо, до якого слід віднести лушпиння соняшника, частинки деревини, солому тощо.

У деяких європейських країнах заміна альтернативного палива в промислових установках досягла майже $100 \%$ на багатьох заводах, i, для подальшого збільшення використання альтернативних видів палива, також розглядається можливість заміни палива, наприклад, в обертових печах [3].

Альтернативні види палива можуть відрізнятися від звичайного викопного палива за характеристиками згоряння через відмінності фізичних і хімічних властивостей і кінетики реакції. До найбільш важливих характеристик відносять розмір часток і вміст вологи [3-5]: альтернативні види палива подрібнюються грубіше, щоб заощадити на подрібненні; у той час як тверде викопне паливо (вугілля), що вводиться, наприклад, у обертову піч, зазвичай має розмір $5 \%$, утримуване на ситі з розміром 90 мікрон, а розмелені альтернативні види палива можуть мати розмір в міліметрах.

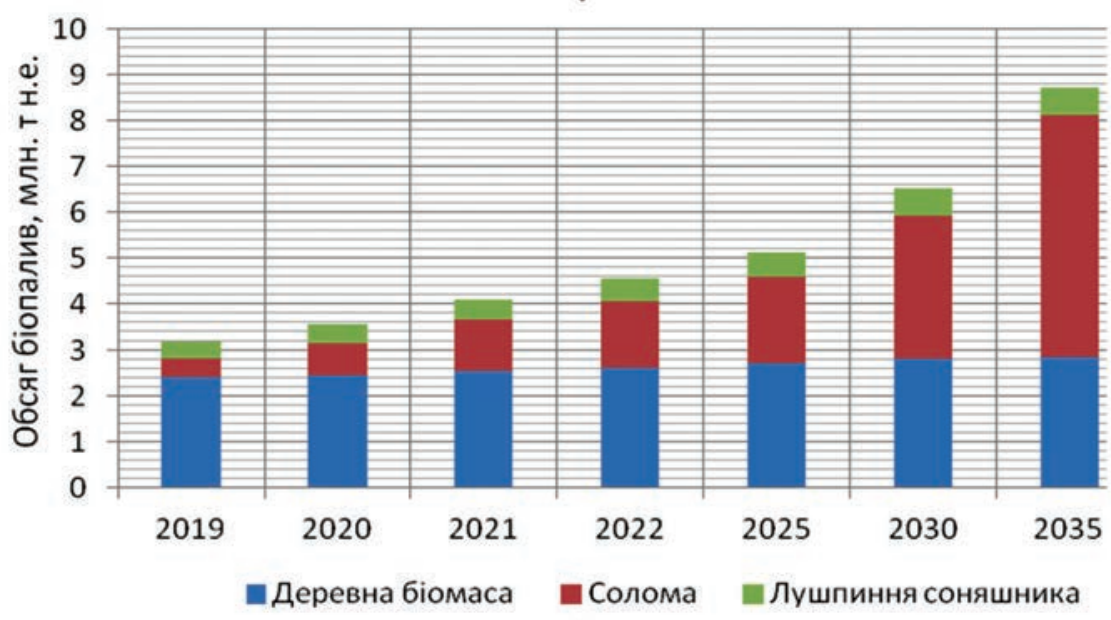

Рис. 1. Прогнозований загальний обсяг та структура споживання біопалив в Україні в 2019-2035 p.p. 


\section{АНАЛІЗ ОСТАННІХ ДОСЛІДЖЕНЬ І ПУБЛІКАЦІЙ}

Відповідно до даних, що наведені в [1], загальний обсяг та структуру споживання біопалив в Україні за прогнозом до 2035 року можна привести у такому вигляді (рис. 1).

Теоретичний потенціал виробництва біогазу з біопалива (відходи та побічна продукція агропромислового комплексу) складає 1,6 млрд. м³ метану. Використати цей потенціал можливо в обсязі $50 \%$ або 0,68 млн. т н.е. Теоретичний потенціал виробництва біогазу із твердих побутових відходів складає 0,6 млрд. м ${ }^{3}$ метану, використати потенціал якого можна в обсязі $34 \%$ або 0,18 млн. т н.е.

Відповідно до роботи [1] розподілення енергетичного потенціалу біопалива 3 деревини та агровідходів у кожній територіальній одиниці (області) України виглядає таким чином (рис. 2).

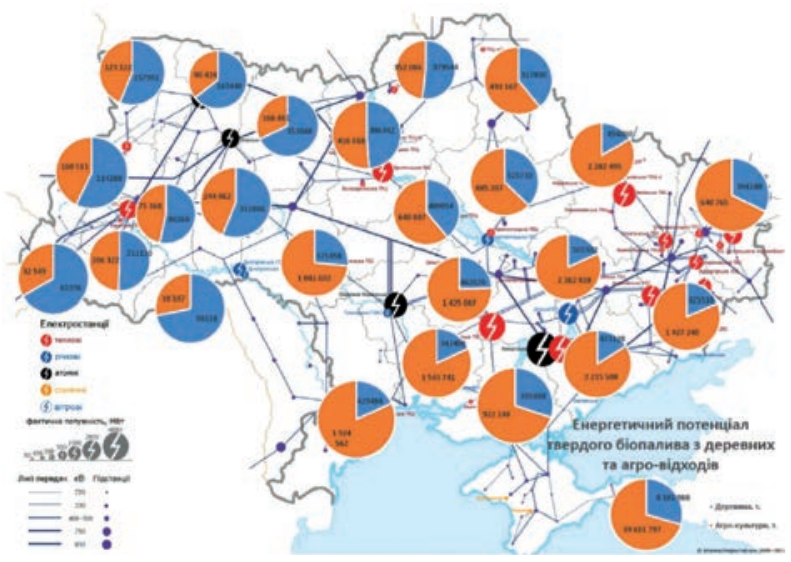

Рис. 2. Розподілення енергетичного потенціалу біопалива 3 деревини та агровідходів в України

На даний момент часу підприємствами України виробляється біопалива в обсязі 5185 тис. т в рік, що є тільки 17\% від технічно можливого потенціалу. При цьому значення середнього коефіцієнту паливної складової частини в теплогенерації в порівнянні з природним газом складає 2,1 , що, в сучасних реаліях, $є$ замалим.

Відомо, що в 2015 році біопалива замістили використання понад 2,63 млрд. м $^{3}$ / рік природного газу в Україні.

Відповідно до Національного плану дій, до 2020 року необхідно виконати заміну 7,2 млрд м 3 газу біопаливом, що відповідає обсягу біля 11882 тис. т / рік біопалива. Це є можливим, якщо буде надаватись державна та міжнародна підтримка.

\section{ВІДОКРЕМЛЕННЯ НЕ ВИРІШЕНИХ РАНІШЕ ЧАСТИН ЗАГАЛЬНОЇ ПРОБЛЕМИ}

Необхідно встановити можливості використання біопалива в технологічних печах, зокрема в обертових. Визначення такої принципової можливості можливо на базі даного дослідження.

\section{МЕТА ДОСЛІДЖЕННЯ}

Виконати аналіз та дослідити особливості прямого спалювання біомаси (лушпиння соняшника, частинок деревини) в промислових обертових печах відповідно до вимог забезпечення енергетичної та екологічної ефективності використання біомаси для заміщення природного газу.

\section{МЕТОДИ, ОБ'ЄКТ ТА ПРЕДМЕТ ДОСЛІДЖЕННЯ}

Під час проведення досліджень використано метод теоретичного аналізу процесу спалювання біопалива в технологічних (обертових печах) 3 подальшим прогнозуванням ефективності їх роботи при заміщенні природного газу на альтернативні палива - біомасу 3 лушпиння соняшника та частинок деревини. Відповідно до поставленої задачі даної публікації об'єктом дослідження є процеси заміщення природного газу в обертових печах на біомасу, а предметом дослідження $\epsilon$ технологічні особливості спалювання біомаси в печах при виконанні вимог 3 енергетичної та екологічної ефективності роботи паливних агрегатів.

\section{ОСНОВНИЙ МАТЕРІАЛ}

При використанні частинок біопалива повинно бути забезпечено ефективне та повне їх згорання з екологічно прийнятними шкідливими викидами. Процес горіння повинен забезпечувати високу ступінь використання енергії, а отже, повне вигорання частинок біопалива, і не повинен викликати утворення небажаних в екологічному відношенні з’єднань [3; 5; 6].

Першим етапом процесу згоряння частинок біопалива є висушування, а далі піроліз / газифікація / пряме спалювання. Однак відносне значення даних етапів залежить від застосовуваної технології спалювання, характеристик частинок біопалива і умов процесу їх горіння. Також можливий поділ етапів висушування - піролізу - газифікації - прямого спалювання, що застосовується, наприклад, при спалюванні біопалива із ступінчастою подачею повітря. На установках спалювання біопалива великої потужності з безперервною іiї подачею, ці процеси відбуваються на різних ділянках печі $[3 ; 5]$.

На рис. 3 приведено якісну схему процесу спалювання (горіння) частинок біопалива. Стадії горіння частинки біопалива є типовими при вигоранні твердого палива та при протіканні процесу горіння послідовно протікають процеси випаровування вологи, виходу (випаровування) летючих горючих речовин та горіння вуглецю і СО.

Виконати систематизацію технологій спалювання біопалива достатньо складно. Пов'язано це $з$ великими темпами розвитку споживання біопалива людством. Розроблено величезну кількість різних біопалив, i, відповідно, методів їх спалювання. Головним чином, методи спалювання біопалива відрізняються за видом та основними принципами його спалювання. 


\section{ТЕПЛОЕНЕРГЕТИКА № 1 2021}

Для порівняння різних технологій спалювання потрібно досконально зрозуміти класифікацію технологій спалювання біопалива, яку представимо за вологістю та ступенем його підготовленості.

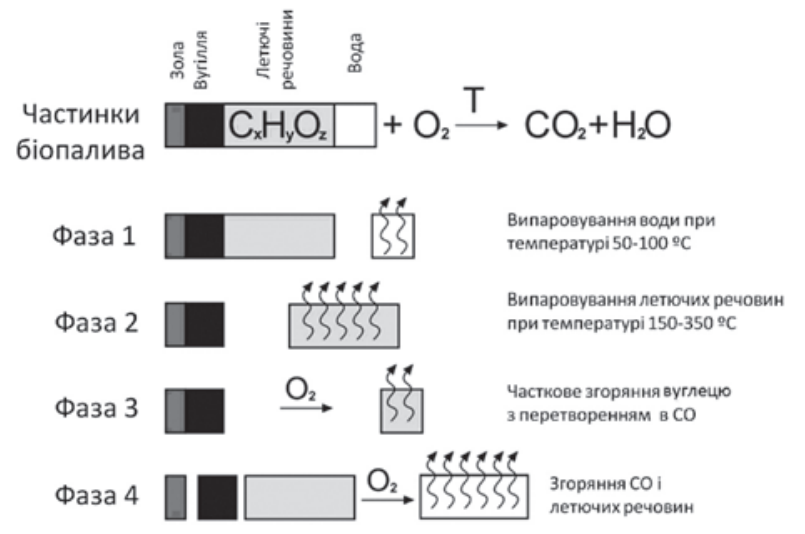

Рис. 3. Схема процесу горіння частинок біопалива

Температура горіння частинок біопалива безпосередньо пов'язана з рівнем їх вологості. Основні категорії технології горіння частинок біопалива (класифікація побудована в залежності від вологості і ступеня підготовленості палива):

1) вологі частинки біопалива (даний вид $є$ найважче спалюваним), при цьому вологість становить 31-55\%, рівень зольності - високий, розмір - не стандартизований;

2) непідготовлене (сухе) біопаливо, до якого відносяться, головним чином - тирса, стружка, відходи від сушки зерна, солома, лузга тощо; вологість не перевищує $30 \%$, зольність і розмір не мають чітко визначених стандартів;

3) рафіноване біопаливо, яке являє собою паливні гранули і брикети, а також паливний пил; мінімальна вологість становить близько 10\%, мінімальна зольність - близько $2 \%$, розміри частинок палива підігнані під спеціальні стандарти.

Для спалювання різних видів частинок біопалива кількість підведеного повітря варіюється. По відношенню до підведеного повітря виділяють такі способи горіння біологічного палива:

1) шарове, яке застосовують при спалюванні великого, кускового біопалива;

2) вихрове, яке використовують для роботи 3 дрібно фракційними частинками біопалива.

Вихрове горіння є самим високотехнологічним методом спалювання частинок біопалива.

До основних технологічних видів палива, які використовуються в промислових обертових печах відносяться кам'яне вугілля і природний газ [3; 5; 7].

Для спалювання в обертових печах паливо повинне відрізнятися середнім вмістом летючих речовин (10-30\%), що визначає довжину зони випалу $[7 ; 8]$.
Сучасна промисловість застосовує вугільне паливо в подрібненому вигляді.

Під час спалювання в обертових печах паливо застосовують в тонкоподрібненому стані, у вигляді пилу [9]. Тонкість помелу повинна бути такою, щоб залишок на ситі № 008 (0,08 мм) знаходився в межах 9-12\% за вагою. При цьому більш грубий помел (близький до $12 \%$ залишку) повинен бути у палива з більш високим вмістом летючих речовин, а більш тонкий - 3 низьким вмістом летючих речовин. Ця вимога виходить 3 умови передчасної газифікації палива при подачі його в топковий простір [9; 10]. Чим більше частинка палива, тим відносно менша кількість його встигне газифікуватися до моменту займання. Однак якщо крупність помелу палива виявиться значною і не відповідатиме вмісту летючих речовин, частинки палива не встигнуть згоріти при своєму польоті і будуть падати на клінкер, догоряючи на ньому і віддаляючись 3 печі в незгорілому стані. У результаті знижується температура факела горіння, підвищується витрата палива і знижується якість.

Серед розмаїття кам'яного вугілля тільки незначна частина їх задовольняє необхідним вимогам [11]. Для отримання палива 3 певними властивостями застосовують змішане паливо, що складається 3 двох, а іноді трьох видів вугілля $[3 ; 5 ; 12]$.

Поряд із наведеними вимогами паливо повинне мати і низьку вологість, тому що зі збільшенням вологості зменшується кількість корисно використовуваного тепла. Значна частина тепла при цьому витрачається на випаровування вологи. Паливо для обертових печей зазвичай застосовують 3 вологістю не більше $2 \%$. Пиловугільне паливо спалюють в розпиленому стані [3; 4; 8; 13].

\section{ОБГОВОРЕННЯ ОТРИМАНИХ РЕЗУЛЬТАТІВ}

Тверді альтернативні види палива мають фізичні та хімічні властивості, які відрізняються від традиційних видів твердого викопного палива. Це створює потребу в новому устаткуванні для спалювання або модернізації існуючих систем обертової печі, тому що альтернативні види палива можуть впливати на стабільність процесу і якість продукції [4; 8; 9].

На стабільність процесу в обертовій печі, в основному, має вплив відновлювальних умов на сировинний шар, що збільшує тенденцію до утворення відкладень на вхідному кінці матеріалу обертової печі, в каналі для стояка в печі і на щаблях нижнього циклону. На якість можуть також впливати незначні з’єднання з золи палива або незгорілого вуглецю, що виходить з обертової печі разом з клінкером $[4 ; 5,13]$.

Зарубіжна промисловість [3-5] зацікавлена в заміні викопних видів палива, що застосовуються в обертових печах альтернативними, щоб мінімізувати виробничі витрати і скоротити викиди $\mathrm{CO}_{2}$. Такими новими альтернативними видами палива $є$, 
зокрема, тверді види палива, такі як паливо, отримане 3 відходів (RDF), паливо з шин (TDF), м'ясо-кісткове борошно (MBM), деревні відходи, осад стічних вод, папір, пластик [3; 6; 9].

Паливо з гуми з шин і деревини, які в даному контексті є актуальними видами палива для застосування в обертових печах, підтверджується відповідним аналізом [3; 9]. Нагрівання, сушка та видалення летючих речовин 3 альтернативних видів палива $є$ швидкими процесами, які в першу чергу залежать від теплообміну і розміру часток палива. Видалення летючих часток 3 деревини або шини товщиною 20 мм при $900{ }^{\circ} \mathrm{C}$ становить приблизно 2 хвилини. На відміну від цього, окислення нафтококсу є повільним процесом, який може значно зменшити кількість твердого палива, яке повинно бути використано у вхідному кінці матеріалу обертових печей, через обмежений час перебування. Кілька параметрів контролюють швидкість окислення нафтококсу: об'ємна концентрація кисню, швидкість масопереносу кисню на частки напівкоксу, час конверсії, ступінь заповнення матеріалу шару, розмір i форма частинок напівкоксу. Такі параметри, як температура і швидкість обертання в обертових печах, мають незначний вплив на окислення нафтококсу в залежності від умов.

В умовах країн СНД до альтернативних видів палива для застосування в обертових печах відносяться: торфобрикети, відпрацьовані автомобільні покришки, відходи переробки нафти (нафтококс), в перспективі $є$ тверді побутові відходи, сухі опади стічних вод, високосірчасте і буре вугілля [13].

Висушений осад стічних вод i тверді побутові відходи можуть бути застосовані в обертових печах, які мають вміст вологи від декількох до більш ніж
50\% за масою. Спалювання осаду стічних вод або палива, отриманого $з$ відходів, з великими частками і високим вмістом вологи в обертових печах призводить до подовження полум'я і часу вигоряння, що, інколи, перевищує нормований час. Збільшення швидкості виносу вторинного повітря, процентного вмісту первинного повітря, коефіцієнту надлишку повітря і застосування збагачення киснем необхідно для повної конверсії великих часток альтернативного палива. Однак ці заходи знижують загальну ефективність процесу.

\section{ВИСНОВКИ}

У роботі досліджені особливості прямого спалювання біомаси (лушпиння соняшника, частинок деревини) в промислових обертових печах. При цьому виконаний аналіз потенціалу біопалива для заміщення природного газу на території України показав, що теоретичний потенціал виробництва біогазу з біопалива (відходи та побічна продукція агропромислового комплексу) складає 1,6 млрд. м³ метану, а використати цей потенціал можливо в обсязі $50 \%$ або 0,68 млн. т н.е. На даний момент часу підприємствами України виробляється біопалива в обсязі 5185 тис. т в рік, що $є$ тільки $17 \%$ від технічно можливого потенціалу.

Розглядаючі світовий досвід прямого спалювання твердого палива в обертових печах, установлено, що основними технологічними видами палив $\epsilon$ кам'яне вугілля і природний газ. Світовий досвід показав, що новими альтернативними видами прямого спалювання твердого палива в обертових печах $\epsilon$, зокрема, тверді види палива, такі як паливо, отримане 3 відходів (RDF), паливо з шин (TDF), м'ясо-кісткове борошно (MBM), деревні відходи, осад стічних вод, папір і пластмаси.

\section{REFERENCES}

[1] Zhelezna T.A. (2018). Analysis of the sector of use of waste from pruning and removal of perennial agricultural plantations for energy purposes in Ukraine. Renewable energy from pruning and uprooting of perennial agricultural plantations: development of production chains as a step towards economic and environmental efficiency: materials of the all-Ukrainian workshop within the uP_running project (Kyiv, February 22, 2018), Kiev, p. 27. [in Russian]

[2] Road map for the development of the solid biofuel market of Ukraine. Kyiv: UNDP/GEF "Development and Commercialization of Bioenergy Technologies in the Municipal Sector in Ukraine", 74 p. [in Russian]

[3] Norskov L.K., Dam-Johansen K., Glarborg P., Jensen P.A., \& Larsen M. B. (2012). Combustion of solid alternative fuels in the cement kiln burner: Industrial PhD thesis. Kgs. Lyngby: Technical University of Denmark (DTU), 162 p.

[4] Tsiliyannis C.A. (2012). Alternative fuels in cement manufacturing: Modeling for process optimization under direct and compound operation. Fuel. Vol. 99. P. 20-39.

[5] Bapat J.D. (2016) Advanced fuel burning technologies in cement production. Indian Cement Review. Vol. 30 , No. 6. P. $44-46$.

[6] Corcuera A. (2004). Refractory steels: AFs and corrosion problems. World Cement. Vol. 35. P. 99 - 102.

[7] Jons E.S., Ostergaard, M.J. (2001). Kiln Shell Corrosion. IEEE-IAS/PCA Cement Industry Technical Conference. Vancouver, British Columbia, Canada, P. 343 - 359.

[8] Klischat H.-J., Liever H., Wirsing, H. (2002). Alkali-resistant linings for the security and preheating zones in rotary cement and lime kilns subject to chemical attack. ZKG International. No. 6. P. 66-75.

[9] Aho M., Ferrer E. (2005). Importance of coal ash composition in protecting the boiler against chlorine deposition during combustion of chlorine-rich biomass. Fuel. Vol. 84. No. 2-3. P. $201-212$.

[10] Chen J. H., Chen K. S., Tong L. Y. (2001). On the pyrolysis kinetics of scrap automotive tires. Journal of hazardous materials. Vol. 84. No. 1. P. $43-55$. 
[11] Chen T. (2011) Effect of hot vapor filtration on the characterization of bio-oil from rice husks with fast pyrolysis in a fluidized-bed reactor. Bioresource technology. Vol. 102. No. 10. P. $6178-6185$.

[12] Chinyama M.P.M., Lockwood F.C. (2007). Devolatilisation behaviour of shredded tyre chips in combusting environment. Journal of the Energy Institute. Vol. 80. No. 3. P. $162-167$.

[13] Podluzskij E.Ya., Turovskij L.N., Novikov V.S., Volotkovich D.I. (2013). Alternative fuels in the production of construction materials of the Republic of Belarus // Scientific and technical problems of using alternative fuels in the construction industry of the Republic of Belarus: materials of the VII International scientific and technical conference. Minsk, October 30, 2013. Minsk. P. 6 - 9. [in Russian]

\section{СПИСОК ВИКОРИСТАНОЇ ЛІТЕРАТУРИ}

[1] Желєзна Т.А. Аналіз сектору використання відходів від обрізки та видалення багаторічних сільськогосподарських насаджень в енергетичних цілях в Україні. Відновлювана енергія з обрізків та викорчовування багаторічних аграрних насаджень: розвиток виробничих ланцюгів як крок до економічної і екологічної ефективності: матеріали всеукраїнського воркшопу в рамках проекту uP_running (м. Київ, 22 лют. 2018 р.). Київ. С. 27.

[2] Коломийченко М. В. Дорожня карта з розвитку ринку твердого біопалива України. Київ : ПРООН/ГЕФ «Розвиток та комерціалізація біоенергетичних технологій у муніципальному секторі в Україні». 2016. 74 с.

[3] Norskov L.K., Dam-Johansen K., Glarborg P., Jensen P.A. \& Larsen M.B. (2012). Combustion of solid alternative fuels in the cement kiln burner: Industrial PhD thesis. Kgs. Lyngby : Technical University of Denmark (DTU), 201 p.

[4] Tsiliyannis C.A. (2012). Alternative fuels in cement manufacturing: Modeling for process optimization under direct and compound operation. Fuel. 2012. Vol. 99. P. 20-39.

[5] Bapat J.D. Advanced fuel burning technologies in cement production. Indian Cement Review. 2016. Vol. 30, No. 6. P. $44-46$.

[6] Corcuera A. Refractory steels: AFs and corrosion problems. World Cement. 2004, Vol. 35. P. 99-102.

[7] Jons E.S. Ostergaard, M.J. Kiln Shell Corrosion. IEEE-IAS/PCA Cement Industry Technical Conference. Vancouver, British Columbia, Canada. 2001. P. 343-359.

[8] Klischat H.-J., Liever H., Wirsing, H. Alkali-resistant linings for the security and preheating zones in rotary cement and lime kilns subject to chemical attack. ZKG International. 2002. No. 6. P. 66-75.

[9] Aho M., Ferrer E. Importance of coal ash composition in protecting the boiler against chlorine deposition during combustion of chlorine-rich biomass. Fuel. 2005. Vol. 84. No. 2-3. P. 201-212.

[10] Chen J.H., Chen K.S., Tong L.Y. On the pyrolysis kinetics of scrap automotive tires. Journal of hazardous materials. 2001. Vol. 84. No. 1. P. 43-55.

[11] T. Chen. Effect of hot vapor filtration on the characterization of bio-oil from rice husks with fast pyrolysis in a fluidized-bed reactor. Bioresource technology. 2011. Vol. 102. No. 10. P. 6178-6185.

[12] Chinyama M.P.M., Lockwood F.C. Devolatilisation behaviour of shredded tyre chips in combusting environment. Journal of the Energy Institute. 2007, Vol. 80. No. 3. P. 162-167.

[13] Подлузский Е.Я., Туровский Л.Н., Новиков В.С., Волоткович Д.И. Альтернативные виды топлива в производстве строительных материалов Республики Беларусь. Научно-технические проблемы использования альтернативных видов топлива в строительном комплексе Республики Беларусь: материаль VII Международной научно-технической конферениии. Минск, 30 октября 2013 г. Минск. С. 6-9.

(C) Лисенко А. А., Воробйов М. В. Дата надходження статті до редакції: 10.03.2021 Дата затвердження статті до друку: 24.03.2021 